\title{
PENGARUH PELAKSANAAN MANAJEMEN KONFLIK OLEH KEPALA RUANGAN PADA MOTIVASI KERJA PERAWAT PELAKSANA DI RUMAH SAKIT MARTHA FRISKA MEDAN
}

\author{
Adventy Riang Bevy Gulo \\ Program Studi Ners Fakultas Farmasi dan Ilmu Kesehatan, Universitas Sari Mutiara Indonesia \\ E-mail : adventy_gulo@yahoo.com
}

\begin{abstract}
Nurses are one of the most important professions in providing services in hospitals, therefore nurses must be able to display optimal performance. Many things can affect nurse performance including conflict and work motivation. Head nurses is demanded to be able to manage conflicts that will have an impact on the work motivation of implementing nurses in providing nursing care in hospitals. This type of research uses quantitative research methods with cross sectional research design that is collecting data on the implementation of conflict management of head nurse and the work motivation of implementing nurses used in the same time and measured once. Sampling in this study used simple random sampling in which there were 59 nurses involved. Bivariate analysis uses chi-square statistical tests to determine the relationship between the implementation of conflict management of head nurse that is good, enough, and less with the nurses' work motivation that strong, medium and weak. The results showed that the majority of conflict management of head nurse was $54.2 \%$ (enough) and the majority of nurses' work motivation was $57.6 \%$ (medium). Chi square statistical test results indicate that there is an influence between the implementation of conflict management of head nuse on the nurses work motivation ( $p$ value $=0,000, \alpha=0.05$ ). Management, communication and good cooperation between health service providers Improving skills in conflict in hospitals is an important thing that must be improved and carried out of head nurse. The hospital management is also expected to pay attention in terms of human resource development, especially conflict management, and optimize the implementation of programmatic conflict management that affects the nurses' work motivation.
\end{abstract}

Keywords: Conflict Management, Nurses' Work Motivation

\begin{abstract}
Abstrak
Perawat merupakan salah satu profesi yang paling berperan penting dalam memberikan pelayanan dirumah sakit, oleh karena itu perawat harus mampu menampilkan kinerja yang optimal. Banyak hal yang dapat mempengaruhi kinerja perawat termasuk adanya konflik dan motivasi kerja. Kepala ruangan dituntut dapat memanajemen konflik yang akan berdampak pada motivasi kerja perawat pelaksana dalam memberikan asuhan keperawatan di rumah sakit. Jenis penelitian ini menggunakan metode penelitian kuantitatif dengan desain penelitian cross sectional yaitu melakukan pengumpulan data pelaksanaan manajemen konflik oleh kepala ruangan dan motivasi kerja perawat pelaksana yang digunakan dalam waktu yang sama dan diukur satu kali saja. Pengambilan sampel dalam penelitian ini menggunakan simple random sampling dimana perawat pelaksana yang diikutsertakan berjumlah 59 orang. Analisis bivariat menggunakan uji statistik chisquare untuk mengetahui hubungan antara pelaksanaan manajemen konflik oleh kepala ruangan yang baik, cukup, dan kurang dengan motivasi kerja perawat pelaksana yang kuat, sedang dan lemah. Hasil penelitian menunjukkan bahwa mayoritas pelaksanaan manajemen konflik oleh kepala ruangan adalah cukup sebanyak $54,2 \%$ dan mayoritas motivasi kerja perawat adalah sedang sebanyak 57,6\% di Rumah Sakit Martha Friska Medan. Hasil uji statistik chi square menunjukkan bahwa ada pengaruh antara pelaksanaan manajemen konflik oleh kepala ruangan pada motivasi kerja perawat pelaksana ( $p$ value $=0,000, \alpha=0,05$ ). Meningkatkan keterampilan dalam memanajemen konflik, komunikasi dan kerjasama yang baik antar pemberi pelayanan kesehatan di rumah sakit untuk merupakan hal penting yang harus ditingkatkan dan dilakukan oleh kepala ruangan. Pihak manajemen rumah sakit juga diharapkan memberi perhatian dalam hal
\end{abstract}


pengembangan SDM khususnya manajemen konflik, dan mengoptimalkan pelaksanaan manajemen konflik secara terprogram yang berpengaruh pada motivasi kerja perawat pelaksana.

Kata Kunci : Manajemen Konflik, Motivasi Kerja

\section{PENDAHULUAN}

Rumah sakit sebagai salah satu organisasi penghasil jasa dituntut untuk menyediakan pelayanan keperawatan yang bermutu. Salah satu profesi yang paling berperan penting di RS adalah perawat. Keperawatan sebagai organisasi profesi berpotensi besar dalam pelaksanaan asuhan keperawatan di rumah sakit. Oleh karena itu, perawat dituntut memiliki kinerja yang optimal. Faktor yang turut mempengaruhi tinggi rendahnya kinerja perawat dalam melaksanakan pelayanan keperawatan dirumah sakit adalah adanya konflik, pengambilan keputusan, gaya kepemimpinan, supervisi, dan motivasi kerja. Konflik mempengaruhi kinerja terhadap keselamatan pasien (Swanburg, 2000). Aamodt (2010) mengatakan bahwa karyawan yang memiliki motivasi kerja rendah, maka akan memiliki kepercayaan diri yang rendah dan kebutuhan akan pencapaian prestasi yang rendah juga.

Keberadaan motivasi sebagai faktor potensial mempengaruhi kinerja organisasi dalam memberikan pelayanan medis sangat bersifat substansial , bahwa motivasi bagian dari proses yang dapat meningkatkan atau menurunkan keinginan dan komitmen individu untuk mencapai tujuan personal dan organisasi melalui motivasi (Nawawi, 2013).

Faktor yang turut mempengaruhi tinggi rendahnya motivasi kerja perawat dalam melaksanakan pelayanan keperawatan di rumah sakit salah satunya adalah adanya konflik. Jika kondisi fisik, emosional, dan mental perawat kurang baik maka hal ini akan berdampak pada pelayanan keperawatan yang diberikan pada pasien. Pieter (dalam Limonu, 2013) menyatakan bahwa salah satu faktor yang mempengaruhi perilaku seseorang adalah motivasi. Brinkert (2010) menjelaskan bahwa konflik yang terjadi di antara tenaga kesehatan di rumah sakit dapat mengakibatkan kerugian seperti kelalaian dalam pengobatan dan perawatan pasien sehingga rumah sakit harus mengeluarkan biaya langsung dan tidak langsung untuk mengatasi konflik.

Pada organisasi keperawatan, konflik terjadi secara alami dan merupakan fenomena yang dapat terjadi karena sumber daya di dalamnya berhubungan secara interpersonal memiliki perbedaan (Marquis \& Huston, 2010). Hasil penelitian yang dilakukan oleh Maisoglou (2014) ditemukan bahwa beban kerja $(83,4 \%)$, kurangnya deskripsi yang jelas mengenai pekerjaan $(63,2 \%)$, alokasi sumber daya yang tidak adil $(59,5 \%)$ dan rendahnya pengakuan atasan $(68,1 \%)$ merupakan sumber-sumber terjadinya konflik. Hasil penelitian mengemukakan bahwa ada hubungan yang bermakna anatara pelaknsanaan manajemen konflik dengan motivasi kerja perawat (Arini, 2012). Penelitian yang dilakukan Rahmadita (2013) menemukan hasil bahwa terdapat hubungan negatif antara konflik peran ganda dan motivasi kerja, ketika konflik peran ganda tinggi maka motivasi kerja pada karyawati menurun. Apapun penyebab dan bentuk dari konflik itu harus segera diatasi/ditangani, karena akan tercipta suasana kerja yang kurang kondusif. Meskipun typical orang itu berbeda-beda tetapi ketika ada konflik dalam pekerjaannya/lembaga kerjanya tentunya akan mempengaruhi motivasi kerja mereka. Dari hasil-hasil penelitian dan teori di atas telah disebutkan faktor-faktor yang mempengaruhi motivasi, selain faktor ekstern seperti: lingkungan kerja (sangat berpengaruh), rasa kebersamaan, kepemimpinan juga sangat ditentukan faktorfaktor intern yang melekat pada setiap orang atau bawahan, seperti pembawaan, tingkat pendidikan, pengalaman masa lampau, dan keinginan atau harapan masa depan.

Pengelolaan konflik sangat berhubungan penting dengan peran kepala ruangan dalam mengelola konflik yang 
konstruktif untuk menciptakan lingkungan yang produktif. Kepala ruangan harus mampu mengenali adanya konflik dan mampu memfasilitasi penyelesaian konflik yang bersifat membangun/konstruktif secepat mungkin (Toren \& Wagner, 2010). Jika konflik mengarah ke suatu yang menghambat, maka kepala ruangan harus mengidentifikasi sejak awal dan secara aktif melakukan intervensi supaya tidak berefek pada produktifitas dan motivasi kerja. Belajar menangani konflik secara konstruktif dengan menekankan pada win-win solution merupakan keterampilan dalam suatu manajemen (Nursalam, 2011). Hasil penelitian Rahayu (2017) mengemukakan bahwa motivasi kerja perawat berada pada kategori lemah sebanyak $48 \%$ dalam melaksanakan asuhan keperawatan sedangkan penelitian lainnya yang di lakukan Rahman, dkk (2018) mayoritas perawat memiliki motivasi yang tinggi dalam penerapan standar asuhan keperawatan sebanyak 76\%. Kuntoro (2010) sumber menjelaskan bahwa peningkatan dan penurunan motivasi perawat pelaksana di rumah sakit tergantung pada kemampuan kepala ruangan (kepala ruangan perawat) dalam mengelola konflik dengan baik. Berdasarkan hal tersebut di atas dapat disimpulkan bahwa manajemen konflik merupakan hal yang sangat penting di dalam suatu organisasi, secara khusus rumah sakit karena sangat mempengaruhi motivasi perawat yang akan sangat berdampak pada mutu pelayanan rumah sakit terhadap masyarakat.

\section{METODE PENELITIAN}

Jenis penelitian ini menggunakan metode penelitian kuantitatif dengan desain penelitian cross sectional yaitu melakukan pengumpulan data pelaksanaan manajemen konflik oleh kepala ruangan dan motivasi kerja perawat pelaksana yang digunakan dalam waktu yang sama dan diukur satu kali saja. Pengambilan sampel dalam penelitian ini menggunakan simple random sampling dimana perawat pelaksana yang diikutsertakan berjumlah 59 orang di Rumah Sakit Martha Friska Medan.

Instrumen pelaksanaan manajemen konflik menggunakan lembar observasi pada laporan pendokumentasian manajemen konflik di ruangan oleh kepala ruangan. Pendokumentasian ini sebagai catatan atau bukti/bukti penanganan konflik yng telah ataupun belum diselesaikan yang membutuhkan tindak lanjut ke depannya. Pendokumentasian meliputi data konflik, sumber konflik, penanganan konflik dan tindak lanjut penanganan konflik.

Metode pengukuran motivasi kerja perawat berupa kuesioner yang berisi sebanyak 29 pernyataan yang telah digunakan sebelumnya oleh peneliti terdahulu (Zulham, 2015) dan menggunakan skala Likert dengan nilai cronbach's alpha $=$ 0,785 . Pernyataan pada kuesioner dengan pilihan jawaban SS: Sangat setuju (5), S: Setuju (4), KS: Kurang setuju (3), TS : Tidak setuju (2), STS: Sangat Tidak Setuju (1), namun memperhatikan pernyataan positif dan negative apabila jawaban yang benar maka skor tertinggi setiap satu pernyataan adalah 5. Analisis bivariat menggunakan uji statistik chi-square untuk mengetahui hubungan antara pelaksanaan manajemen konflik oleh kepala ruangan yang baik, cukup, kurang, dengan motivasi kerja perawat pelaksana yang kuat, sedang dan lemah.

\section{HASIL PENELITIAN}

Hasil penelitian menunjukkan bahwa distribusi kepala ruangan perawat pelaksana yang menjadi subjek penelitian, mayoritas berjenis kelamin perempuan $72,9 \%$, mayoritas usia responden adalah 21-25 tahun $44,1 \%$ tahun, mayoritas responden berpendidikan D3 Keperawatan 62,7\%, dan mayoritas lama kerja responden 1,1-1,5 tahun $42,4 \%$. Lebih lanjut dijelaskan bahwa mayoritas pelaksanaan manajemen konflik di ruangan adalah cukup sebanyak 54,2\% dan mayoritas motivasi kerja perawat adalah sedang sebanyak $57,6 \%$. Hasil uji statistik chi square menunjukkan bahwa ada pengaruh antara pelaksanaan manajemen konflik oleh 
kepaa ruangan pada motivasi kerja perawat pelaksana $(p$ value $=0,000, \alpha=0,05) \mathrm{di}$ Rumah Sakit Martha Friska Medan.

Tabel 1. Distribusi frekuensi pelaksaaan manajemen konflik oleh kepala ruangan

\begin{tabular}{lll}
\hline $\begin{array}{l}\text { Pelaksanaan } \\
\text { Konflik }\end{array}$ & Manajemen & $f$ \\
\hline Baik & 18 & $30,5 \%$ \\
\hline Cukup & 32 & 54,2 \\
\hline Kurang & 9 & 15,3 \\
\hline Total & 59 & $100 \%$ \\
\hline
\end{tabular}

Tabel 2. Distribusi frekuensi motivasi kerja perawat

\begin{tabular}{lll}
\hline Motivasi Kerja Perawat & $F$ & $\%$ \\
\hline Kuat & 19 & $32,2 \%$ \\
\hline Sedang & 34 & 57,6 \\
\hline Lemah & 6 & 10,2 \\
\hline Total & 59 & $100 \%$ \\
\hline
\end{tabular}

Tabel 3. Hasil uji chi square pengaruh pelaksaaan manajemen konflik oleh kepala ruangan pada motivasi kerja perawat pelaksana

\begin{tabular}{|c|c|c|c|c|c|}
\hline \multirow{2}{*}{$\begin{array}{l}\text { Pelaksana } \\
\text { an } \\
\text { Manajem } \\
\text { en } \\
\text { Konflik }\end{array}$} & \multicolumn{3}{|c|}{$\begin{array}{l}\text { Motivasi } \\
\text { Perawat }\end{array}$} & \multirow[b]{2}{*}{$\begin{array}{l}\text { Tot } \\
\text { al }\end{array}$} & \multirow[b]{2}{*}{$\begin{array}{l}p \\
\text { value }\end{array}$} \\
\hline & $\begin{array}{l}\text { Kua } \\
\mathrm{t}\end{array}$ & $\begin{array}{l}\text { Seda } \\
\text { ng }\end{array}$ & $\begin{array}{l}\text { Lema } \\
\mathrm{h}\end{array}$ & & \\
\hline Baik & $\begin{array}{l}15 \\
(25, \\
4 \%)\end{array}$ & $\begin{array}{l}1 \\
(1,7 \% \\
)\end{array}$ & $\begin{array}{l}2 \\
(3,4 \% \\
)\end{array}$ & $\begin{array}{l}18 \\
(30 \\
5 \\
\%)\end{array}$ & \multirow{4}{*}{0,000} \\
\hline Cukup & $\begin{array}{l}2 \\
(3,4 \\
\%)\end{array}$ & $\begin{array}{l}27 \\
(45,8 \\
\%)\end{array}$ & $\begin{array}{l}3 \\
(5,1 \% \\
)\end{array}$ & $\begin{array}{l}32 \\
(54 \\
2 \\
\%)\end{array}$ & \\
\hline Kurang & $\begin{array}{l}2 \\
(3,4 \\
\%)\end{array}$ & $\begin{array}{l}6 \\
(10,2 \\
\%)\end{array}$ & $\begin{array}{l}1 \\
(1,7 \% \\
)\end{array}$ & $\begin{array}{l}9 \\
(15 \\
3 \\
\%)\end{array}$ & \\
\hline Total & $\begin{array}{l}19 \\
(32, \\
2 \%)\end{array}$ & $\begin{array}{l}34 \\
(57,6 \\
\%)\end{array}$ & $\begin{array}{l}6 \\
(10,2 \\
\%)\end{array}$ & $\begin{array}{l}59 \\
(10 \\
0 \% \\
)\end{array}$ & \\
\hline
\end{tabular}

\section{PEMBAHASAN}

\section{Pelaksanaan Manajemen Konflik Oleh Kepala Ruangan}

Pelaksanaan manajemen konflik sangatlah penting dalam meningkatkan produktivitas rumah sakit. Hal ini dikarenakan pengelolaan konflik yang baik oleh kepa ruangan dapat berpengaruh pada motivasi kerja perawat dalam memberikan asuhan keperawatan. Distribusi frekuensi pelaksanaan manajemen konflik oleh kepala ruangan menunjukkan bahwa mayoritas pelaksanaan manajemen konflik di ruangan adalah cukup sebanyak 54,2\%. Pelaksanaan manajemen konflik yang dilakukan kepala ruangan dapat dilihat dari lembar observasi sebagai laporan pendokumentasian manajemen konflik di ruangan oleh kepala ruangan yang meliputi data konflik, sumber konflik, penanganan konflik dan tindak lanjut penanganan konflik.

Wirawan (2013) mengemukakan bahwa gaya manajemen konflik adalah suatu atau beberapa pola yang membentuk suatu perilaku yang digunakan untuk menghadapi situasi konflik. Faktor-faktor yang mempengaruhi gaya manajemen konflik yang digunakan diantaranya asumsi mengenai konflik, persepsi mengenai penyebab konflik, ekspektasi atas reaksi lawan konfliknya, pola komunikasi dalam interaksi konflik, kekuasaan yang dimiliki, pengalaman menghadapi situasi konflik, sumber yang dimiliki, jenis kelamin, kecerdasan emosional, kepribadian, budaya organisasi sistem sosial, prosedur yang mengatur pengambilan keputusan jika terjadi konflik, situasi konflik dan posisi dalam konflik, pengalaman menggunakan salah satu gaya manajemen konflik, dan keterampilan berkomunikasi.

Kepala ruangan pada dasarnya harus mengetahui tahapan konflik yang terjadi diruangan, baik konfik yang masih dirasakan, konflik yang tampak maupun akibat dari konflik tersebut (Marquis \& Hutson, 2010). Berdasarkan hasil penelitian didapatkan bahwa konflik yang sering terjadi adalah dalam suatu organisasi rumah sakit khususnya bagi perawat diantaranya perilaku 
menentang, stres, ruang, kewenangan dokter, keyakinan, nilai, dan sasaran, serta penyebab lainnya (Swanburg, 2000).

Pelaksanaan manajemen konflik adalah suatu proses pihak yang terlibat konflik atau pihak ketiga menyusun strategi konflik dan menerapkannya untuk mengendalikan konflik agar menghasilkan resolusi yang diinginkan. Manajemen konflik harus dilakukan secara sistematis untuk mencapai suatu tujuan, di antaranya mencegah gangguan kepada anggota organisasi dalam mencapai visi, misi dan tujuan organisasi, memahami orang lain dan menghargai keberagaman, meningkatkan kreativitas, meningkatkan keputusan melalui pertimbangan-pertimbangan, memfasilitasi pelaksanaan kegiatan melalui peran serta, pemahaman bersama, dan kerja sama, serta menciptakan prosedur dan mekanisme penyelesaian konflik (Wirawan, 2013).

Manajemen konflik dapat dilakukan dengan banyak hal, salah satunya keterampilan khusus yang harus dimiliki oleh seorang manajer perawatan (Swanburg, 2000). Pelaksanaan manajemen konflik oleh kepala ruangan mayoritas cukup dikarenakan kepala ruangan dalam memanajemen konflik belum maksimal. Ada beberapa konflik yang ditemukan tetapi tidak diselesaikan sampai tuntas dan ada konflik yang terjadi tetapi tidak dapat dirasakan oleh kepala ruangan. Para kepala ruangan juga terkadang membiarkan konflik yang dianggap sepele atau kecil, mereka kurang menyadari bahwa konflik yang besar tidak jarang dimulai dari konflik yang kecil. Selain ini ditemukan bahwa banyak konflik yang diselesaikan tetapi tidak didokumentasikan sehingga pihak terkait tidak paham hasil keputusan akhir dari penyelesaian konflik tersebut.

Kurang optimalnya pelaksanaan manajemen konflik juga didasarkan pada kurangnya controlling pada pendokumentasian manajemen oleh top manajer. Lebih lanjut dijelaskan bahwa para kepala ruangan pernah mendapatkan pelatihan manajemen konflik di ruangan tetapi hanya sekali saja dalam waktu yang singkat. Keseluruhan hal tersebut di atas menjadi perhatian penting manajemen rumah sakit sehingga pelaksanaan manajemen konflik di ruangan dapat berjalan secara optimal sehingga dapat meningkatkan motivasi perawat pelaksana untuk meningkatkan kinerjanya (Nawawi, 2013).

\section{Motivasi Kerja Perawat Pelaksana}

Motivasi kerja perawat merupakan hal penting dalam menghasilkan kinerja yang optimal untuk meningkatkan mutu pelayanan di rumah sakit. Hasil penelitian menunjukkan bahwa mayoritas motivasi kerja perawat pelaksana adalah sedang sebesar $57,6 \%$. Hasil penelitian ini sejalan dengan hasil penelitian yang dilakukan oleh Talle (2015) yang menunjukkan bahwa motivasi memberi pengaruh signifikan terhadap peningkatan kualitas pelayanan $(p$ value $=0,000)$.

Faktor-faktor yang membentuk motivasi antara lain lain menurut Mangkunegara (2014) adalah sebagai berikut: achievement (prestasi kerja) adalah keberhasilan seorang pegawai dalam menyelesaikan tugas; advancement (pengembangan diri) adalah suatu keinginan seseorang untuk mengembangkan karier dibidang keuangan. Dengan adanya kesempatan untuk maju itu, maka keinginan untuk berkembang tersebut dapat terpenuhi; work it self (pekerjaan itu sendiri) adalah variasi pekerjaan dan kontrol atas metode serta langkah-langkah kerja; recognition (pengakuan) artinya karyawan memperoleh pengakuan adalah orang, berprestasi baik diberi penghargaan, dan pujian; rasa aman (security) adalah dapat melakukan pekerjaann tanpa dibebani resiko yang dapat membahayakan diri karyawan. Adanya perasaan aman merupakan sesuatu yang diinginkan oleh setiap orang, terutama pada saat ia sedang melaksanakan tugas yang merupakan tumpuan hidupnya; reputasi yakni tempat dimana karyawan itu bekerja sudah terkenal dan memiliki nama baik dalam masyarakat sehingga ada kebanggaan pada tempat dimana seseorang bekerja itu akan memberikan keyakinan; teman kerja (coworkers) yaitu teman kerja yang dapat bekerja sama dan berteman dengan baik. Kerja sama dan rasa saling menghargai 
sesama rekan sekerja akan memberikan perasaan tenang dan membutuhkan persatuan dan keakraban yang dapat memperlancar aktivitas kerja.; insentif (gaji) dimana gaji yang dirasakan cukup baik dan pantas bagi dirinya menurut ukurannya sendiri. Hal ini merupakan kebutuhan hidup yang paling mendasar dan merupakan faktor pertama bagi kelangsungan hidup manusia. Dengan dirasakan adanya gaji yang cukup baik, maka diharapkan aktivitas kerja pegawai atau bawahantidak terhambat oleh pemikiran pemikiran bagaimana menghidupi dirinya sendiri dan keluarganya; keadaan tempat kerja (working condition) yang baik misalnya dengan adanya kebersihan, pergantian udara dan subu ruangan kerja dalam kondisi baik; fasilitas-fasilitas lain yang disediakan (benefits) aadalah tersedianya fasilitasfasilitas lain yang terdapat di tempat kerja seperti asuransi kesehatan, transportasi, pengobatan gratis, perumahan dan lain-lain. Tersedianya fasilitas ini semakin memberikan keyakinan bagi pegawai bahwa hidupnya tidak akan disia-siakan dan menjadi terlantar, sehingga keadaan ini dapat menambah kegairahan bekerja.

Motivasi adalah proses psikis yang mendorong orang untuk melakukan sesuatu.

Motivasi kerja seorang perawat tidak dapat diamati secara langsung, tetapi dapat di interpretasikan dari tingkah lakunya. Motivasi kerja dapat di pandang sebagai perubahan energi dalam diri seseorang yang di tandai dengan munculnya feeling terhadap tujuan, termasuk dalam pekerjaan seorang perawat yaitu meningkatkan mutu pelayanan keperawatan. (Hamzah, 2016). Penelitian yang dilakukan oleh Mariah (2015) juga menunjukkan bahwa ada pengaruh motivasi dan kinerja terhadap kualitas pelayanan dengan nilai $r=0,732$. Menurut Hamzah (2016) yang mempengaruhi motivasi kerja itu sendiri adalah motivasi kerja eksternal seperti Bekerja dengan harapan memperoleh upah dan insentif, perhatian dari teman sejawat serta atasan, namun harapan tersebut tidak terealisasikan dengan baik.

\section{Pengaruh Pelaksanaan Manajemen Konflik Pada Motivasi Kerja Perawat Pelaksana}

Hasil penelitian menunjukkan bahwa mayoritas pelaksanaan manajemen konflik oleh kepala ruangan adalah cukup yaitu $54,2 \%$ dengan motivasi kerja perawat pelaksana mayoritas sedang yaitu 57,6\%. Hasil uji statistik chi square menunjukkan bahwa ada pengaruh pelaksanaan manajemen konflik oleh kepala ruangan pada motivasi kerja perawat pelaksana dengan nilai $p$ value $=0,000$. Motivasi kerja perawat adalah dorongan dan keinginan seorang perawat dalam melaksanakan asuhan keperawatan berdasarkan tanggung jawab, pengakuan, komitmen kepemimpinan, upah dan kondisi kerja. (Rahayu, 2017)

Konflik tidak dapat dihindari, maka pendekatan yang baik untuk diterapkan para kepala ruangan adalah mencoba memanfaatkan konflik sedemikian rupa sehingga konflik dapat memberikan hal yang efektif untuk mencapai tujuan organisasi. Konflik dapat menjadi suatu energi yang kuat jika dikelola dengan baik, tetapi sebaliknya jika tidak dapat dikendalikan dengan baik akan mengakibatkan motivasi menurun sehingga kinerja organisasi rendah. Hasil penelitian ini sejalan dengan penelitian yang dilakuakan oleh Abubakar (2008) yang menjelaskan bahwa peningkatan dan penurunan kinerja perawat pelaksana di rumah sakit tergantung pada kemampuan kepala ruangan (kepala ruangan perawat) dalam mengelola konflik dengan baik. Lebih lanjut, penelitian Posthuma (2011) yang menegaskan bahwa terdapat hubungan yang signifikan antara manajemen konflik dan hasil subjektif, seperti persepsi subjektif dari negosiasi, kepuasan kerja, intensitas turnover, dan hubungan antara rekan kerja. Penelitian lainnya juga mengemukakan bahwa ada hubungan yang bermakna antara pelaknsanaan manajemen konflik dengan motivasi kerja perawat (Arini, 2012).

Motivasi dapat berasal dari dalam diri maupun luar diri seseorang. Memotivasi diri apalagi memotivasi orang lain atau bawahan bukanlah pekerjaan yang mudah. 
Rutinitas pekerjaan sering dialami sebagai kejenuhan mendalam yang dapat menurunkan motivasi berprestasi. Hal ini diperparah pula dengan kondisi kerja yang tidak mendukung. Dalam memotivasi orang, manajer atau pimpinan berhadapan dengan dua hal yang mempengaruhi orang dalam pekerjaan yaitu kemauan dan kemampuan. Kemauan dapat diatasi dengan pemberian motivasi, sedangkan kemampuan dapat diatasi dengan mengadakan diklat. Apapun penyebab dan bentuk dari konflik itu harus segera diatasi/ditangani, dengan melaksanakan manajemen konfik sehingga akan tercipta motivasi kerja yang baik.

\section{KESIMPULAN}

Berdasarkan hasil penelitian menunjukkan bahwa mayoritas berjenis kelamin perempuan $72,9 \%$, mayoritas usia responden adalah $21-25$ tahun $44,1 \%$ tahun, mayoritas responden berpendidikan D3 Keperawatan $62,7 \%$, dan mayoritas lama kerja responden $1,1-1,5$ tahun $42,4 \%$. Lebih lanjut dijelaskan bahwa mayoritas pelaksanaan manajemen konflik di ruangan adalah cukup sebanyak $54,2 \%$ dan mayoritas motivasi kerja perawat adalah cukup sebanyak 57,6\% di Rumah Sakit Martha Friska Medan.

Hasil uji statistik chi square menunjukkan bahwa ada pengaruh antara pelaksanaan manajemen konflik oleh kepaa ruangan pada motivasi kerja perawat pelaksana $(p$ value $=0,000, \alpha=0,05)$. Dengan demikian dapat disimpulkan bahwa pelaksanaan manajemen konflik oleh kepala ruangan berpengaruh pada motivasi kerja perawat pelaksana.

\section{SARAN}

Pelaksanaan manajemen konflik di ruangan harus dioptimalkan oleh kepala ruangan dengan cara meningkatkan pengetahuan dan keterampilan kepala ruangan dalam memanajemen konflik di ruangan dengan memberikan pelatihan yang berkelanjutan bagi para kepala ruangan maupun calon kepala ruangan perawat terkait pengembangan SDM khususnya manajemen konflik, dan mengoptimalkan pelaksanaan manajemen konflik secara terprogram yang berpengaruh pada motivasi kerja perawat pelaksana.

Meningkatkan self evaluation komunikasi dan kerjasama yang baik antar pemberi pelayanan kesehatan di rumah sakit untuk meminimalisir konflik yang terjadi di ruangan juga merupakan hal penting yang harus dilakukan oleh kepala ruangan. Kepala ruangan juga harus memiliki keterampilan khusus dlam mengelola konflik, hal ini tidak terlepas dari pengetahuan dan pengalaman menyelesaikan konflik di ruangan. Lebih lanjut diperlukan sikap untuk mengembangkan kemampuan diri dalam pemberian pelayanan keperawatan di ruangan dengan memanfaatkan pelaksanaan manajemen konflik di ruangan dan self education.

\section{REFERENSI}

Abubakar, A. (2008). Pengaruh Pelatihan Manajemen Konflik Pada Kepala Ruangan Terhadap Kinerja Perawat Pelaksana di Ruang Rawat Inap RS dr. H. Marzuki Mahdi Bogor. Jakarta; FIK UI Tesis.

Brinket, R. (2010). A literature review of conflict communication causes, costs, benefits, and intervensions in nursing. Journal of Nursing Management, 18,145-156.

Hamzah, (2016). Teori Motivasi dan Pengukurannya. Jakarta: Bumi Aksara.

Limonu, F. (2013). Hubungan antara motivasi kerja dengan burnout pada perawat di IRD RSUD Dr. M.M Dundo Limboto. (Skripsi tidak dipublikasikan). Program Studi Ilmu Keperawatan Universitas Negeri Gorontalo, Gorontalo.

Maisoglou, I. (2014). Conflict Management in a Greek Public Hospital : Collaboration or Avoidance? International Journal of Caring Sciences. $7,75-82$. 
Marquis \& Huston. (2010). Kepemimpinan dan manajemen keperawatan teori \& aplikasi. Edisi 4. Jakarta: EGC.

Nawawi, (2013). Pengaruh Motivasi dan Kompetensi Tenaga Kerja Kesehatan Terhadap Kinerja Puskesmas.

Polit D. F. \& Beck, C. T. (2012). Nursing Research Generating and Assesing Evidence for Nursing Practice. 9th Edition. William \& Wilkins, Lippicont.

Posthuma, RA. (2011). Conflict Management and Peformance Outcomes. International Journal of Conflict Management. 22 (2), 108-110.

Rahayu, A. (2017). Hubungan Pengetahuan Dan Motivasi Perawat Tentang Terapi Intravena Dengan Pencegahan Plebitis Di Ruang Rawat Inap Rsud Raden Mattaher Kota Jambi 2017. Jurnal Akademika Baiturrahim, Vol. $6, \operatorname{ed}(1)$.

Rahmadita, I. (2013). Hubungan antara konflik peran ganda dan dukungan sosial pasangan dengan motivasi kerja pada karyawati di Rumah Sakit Abdul Rivai-Berau. Ejournal Psikologi Fisip Unmul , 1(1), 58-68

Rahman, dkk. (2018). Hubungan Motivasi Kerja Perawat Pelaksana Dengan Penerapan Standar Asuhan Keperawatan (SAK) di IRNA Kelas III RSUD Ulin Banjarmasi 2018. Jurnal Keperawatan, Vol. 2, ed(1).

Siagian, S.P. (2015). Manajemen Sumber Daya Manusia. Jakarta: Bumi Aksara.

Swanburg, R.C. \& Swanburg, R.J. (2000). Introductory Management and Leadership for Nurses. Second edition. Boston : James and Bartlet publishers.

Toren, O. \& Wagner, N. (2010). Applying an ethical decision-making tool to a nurse management dilemma. Journal of Nursing Etnics, 17 (3), 393-402.

Williams, I. A. (2011). Conflict Management Styles and Job Satisfaction by Organizational Levels and Status in Privat.
Wirawan. (2013). Konflik dan Manajemen Konflik : Teori, aplikasi dan penelitian. Jakarta : Salemba Humanika.

Zulham, H. (2015) Pengaruh kinerja dengan motivasi kerja perawat dalam pelaksanaan asuhan keperawatan di instalasi rawat inap RSU Imelda Pekerja Indonesia Medan tahun 2015 [Skripsi].Medan: Universitas Sumatera Utara. 